\title{
Reproductive biology of the Sompat grunt, Pomadasys jubelini (Cuvier, 1830) in Côte d'Ivoire lagoons complex (West Africa)
}

\author{
Bodji Iridjé Marcelle ${ }^{12}$, Kouadio Justin Konan ${ }^{1}$, Alla Yao Laurent ${ }^{1}$, Ouattara Nahoua Issa ${ }^{2}$, Atsé Boua \\ Célestin 1 \\ ${ }^{1}$ Centre de Recherches Océanologiques (CRO), BP V Abidjan 18, Côte d'Ivoire \\ 2Laboratoire d'hydrobiologie, UFR Biosciences, Université de FHB, 22 BP 584 Abidjan 22 \\ Corresponding author email: atse_boua_celestin@hotmail.com
}

Original submitted in on $7^{\text {th }}$ October 2013 Published online at www.m.elewa.org on 30 2013. https://dx.doi.org/10.4314/jab.v72i1.99673

\begin{abstract}
:
Objectives: To study some aspects of reproductive biology of Pomadasys jubelini (Cuvier, 1830) in the three lagoons complex (Grand-Lahou, Ebrie and Aby) of Côte d'Ivoire in relation to sex ratio, size at first maturity, spawning season and fecundity.

Methodology and results: Fish were sampled with gill nets from January 2007 to December 2008. The whole sample consisted in 2284 specimens with fork length ranging from 8.50 to $32.70 \mathrm{~cm}$ and weight from 8.00 to $780.72 \mathrm{~g}$. The sex ratio was in favour of males with 1:0.82, 1:0.63 and 1:0.56 respectively in GrandLahou, Ebrie and Aby lagoons. The length at first maturity was $14.48 \mathrm{~cm}$ (males) and $15.92 \mathrm{~cm}$ (females) in Grand-Lahou lagoon, $12.13 \mathrm{~cm}$ (males) and $14.70 \mathrm{~cm}$ (females) in Ebrie lagoon, and $14.03 \mathrm{~cm}$ (males) and $15.08 \mathrm{~cm}$ (females) in Aby lagoon. Both monthly gonadosomatic index and macroscopically determined gonad stages indicated that $P$. jubelini spawned from November to April in three lagoons. The absolute fecundity ranged from 46856 to 131208 eggs (Grand-Lahou lagoon), 46184 to 126959 eggs (Ebrie lagoon), and from 17184 to 129459 (Aby lagoon). The frequency distribution of oocytes diameters was unimodal.

Conclusion and application: The results suggest that $P$. jubelini has very good parameters and can be used as farmed fish.
\end{abstract}

Key words: Pomadasys jubelini, Sex ratio, Sexual maturity, Spawning, Fecundity, Lagoons, Côte d'Ivoire.

\section{INTRODUCTION}

Knowledge of reproductive biology of a fish species is essential for effective fishery management (Marshall et al., 2003). Key parameters required for stock assessments are estimated including sex ratio, reproductive season, and size at maturity (Sun et al., 2009). The diversity of the Haemulidae family allows their large distribution throughout the world and covers the Atlantic, Indian and Pacific oceans (Bauchot and Hureau, 1990). Members of this family are commonly referred to as grunt (Bauchot and Hureau, 1990).

In Côte d'Ivoire, fish of the genus Pomadasys are represented by four species which are Pomadasys 
jubelini (Cuvier, 1830), Pomadasys rogeri (Cuvier, 1830), Pomadasys incisus (Bowdich, 1825) and Pomadasys peroteti (Cuvier, 1830). P. jubelini is a Haemulidae naturally occurring in coastal waters, estuaries and freshwaters along the West African coast and from Mauritania to Angola (Paugy et al., 2003). This species is caught by artisanal gears using gill nets, beach seines, long lines and trawls. $P$. jubelini or Sompat grunt is highly appreciated by the population because of its high quality flesh and is one of the commercially important fish in Côte

\section{MATERIALS AND METHODS}

Study area: The present study was conducted in the three lagoons complex (Grand-Lahou, Ebrié and Aby) of Côte d'Ivoire. These lagoon systems are essentially set in the Golf of Guinea between $2^{\circ} 50$ and $5^{\circ} 25$ west longitudes and $5^{\circ} 25$ north latitude (Durand and Skubich, 1982; Durand and Guiral, 1994). These lagoons have an equatorial climate, including two rainy seasons (April - July and October - November), and two dry seasons (December - March and August September). Water length is stretched on $50 \mathrm{~km}, 130$ $\mathrm{km}$ and $30 \mathrm{~km}$ respectively in Grand-Lahou, Ebrié and Aby lagoons. They are permanently connected to the sea from the pass of Grand-Lahou (Grand-Lahou lagoon), the Vridi Canal (Ebrie lagoon) and the pass of Assinie (Aby lagoon) (Durand and Skubich, 1982; Durand and Guiral, 1994). Their surfaces are 190, 532
d'Ivoire. Despite its worldwide importance, little work has been dedicated to this species. The information is about some aspects of reproductive biology (e.g. the sex ratio, the period of reproduction and the fecundity) and the physiology of $P$. jubelini (Fantodji, 1987). The aim of this study is to supply basic information about the reproductive biology of this species in the three lagoons complex (Grand-Lahou, Ebrie and Aby) of Côte d'Ivoire in relation to sex ratio, size at first maturity, spawning season and fecundity.

and $424 \mathrm{~km}^{2}$ respectively in Grand-Lahou, Ebrie and Aby lagoons (Lae, 1982; Durand and Guiral, 1994). According to Durand and Skubich (1979), Grand-Lahou lagoon is divided into two large zones in relation to the hydroclimate: an Eastern zone under the influence of continental and oceanic input and, a Western zone where the marine and continental an influences are less. However, according to the hydroclimate, the primary and secondary production (Durand and Skubich, 1982), Ebrie lagoon is separated by six sectors. The permanent linkage with the Atlantic Ocean produces typical estuarine characteristics, especially in Sectors II, III, and IV which are near the Vridi canal. Conversely, Sectors I, V, and VI are oligohaline, stable, and homogeneous throughout the year (Durand and Guiral, 1994). ).

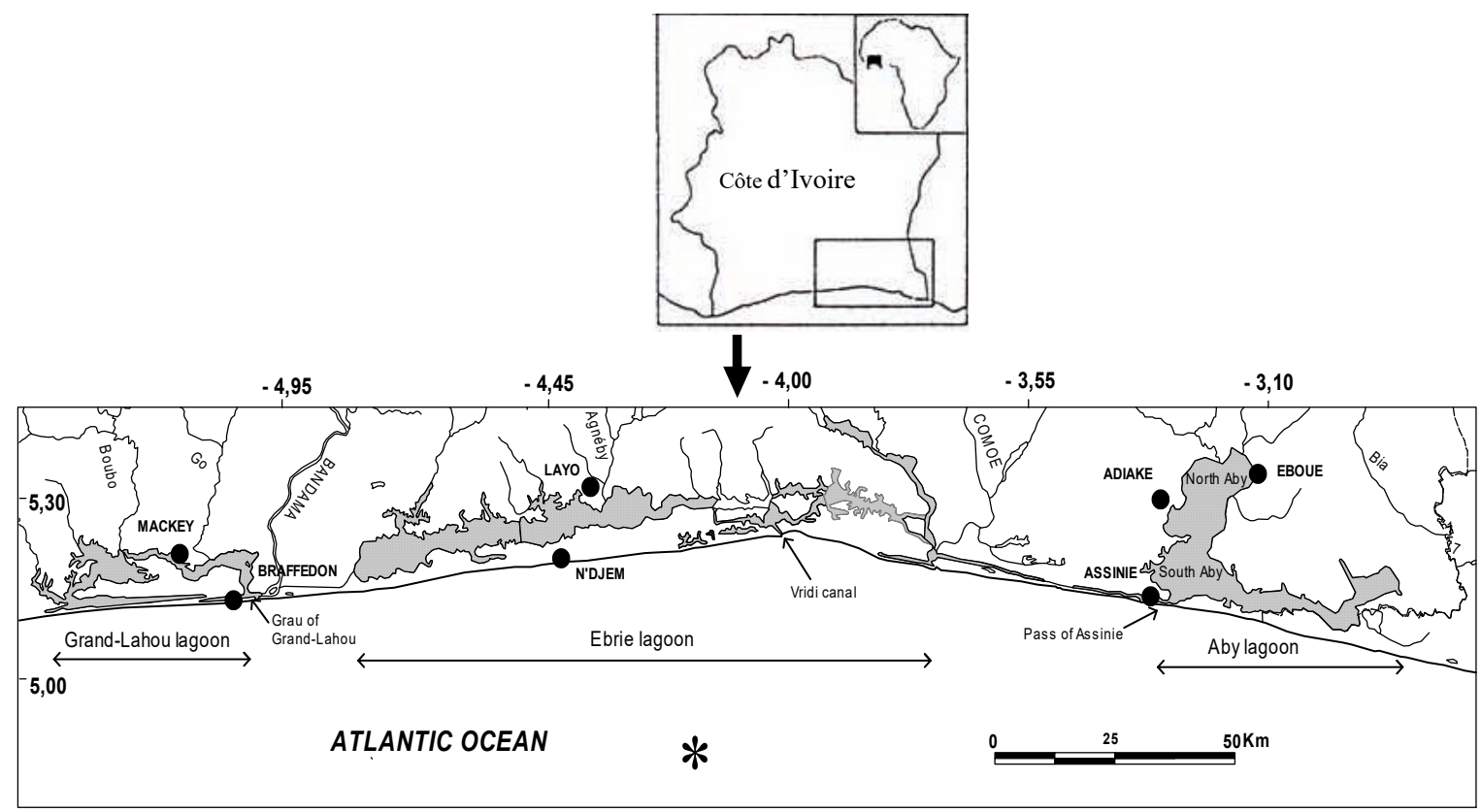


Fig. 1: Sampling areas of samples location (•) from January 2007 to December 2008 in lagoons complex of Côte d'Ivoire (West Africa).

In Aby lagoon, the strata 2 (South Aby) which receives the marine influence is estuarine. In contrast, the strata 1 (North Aby), strata 3 (Tendo), and strata 4 (Ehy) under the continental influence are very stable and oligohaline (Fig. 1).Salinity and water temperature, during the current study ranged from $2.00-20.00 \mathrm{~g} / \mathrm{l}$ and $20.70-30.60^{\circ} \mathrm{C}$ in Grand-Lahou lagoon, from 1.70 $-6.20 \mathrm{~g} / \mathrm{l}$ and $26.9-30.80^{\circ} \mathrm{C}$ in Ebrie lagoon, and from $0.81-8.54 \mathrm{~g} / \mathrm{l}$ and $26.95-32.00^{\circ} \mathrm{C}$ in Aby lagoon (Fig. 2).
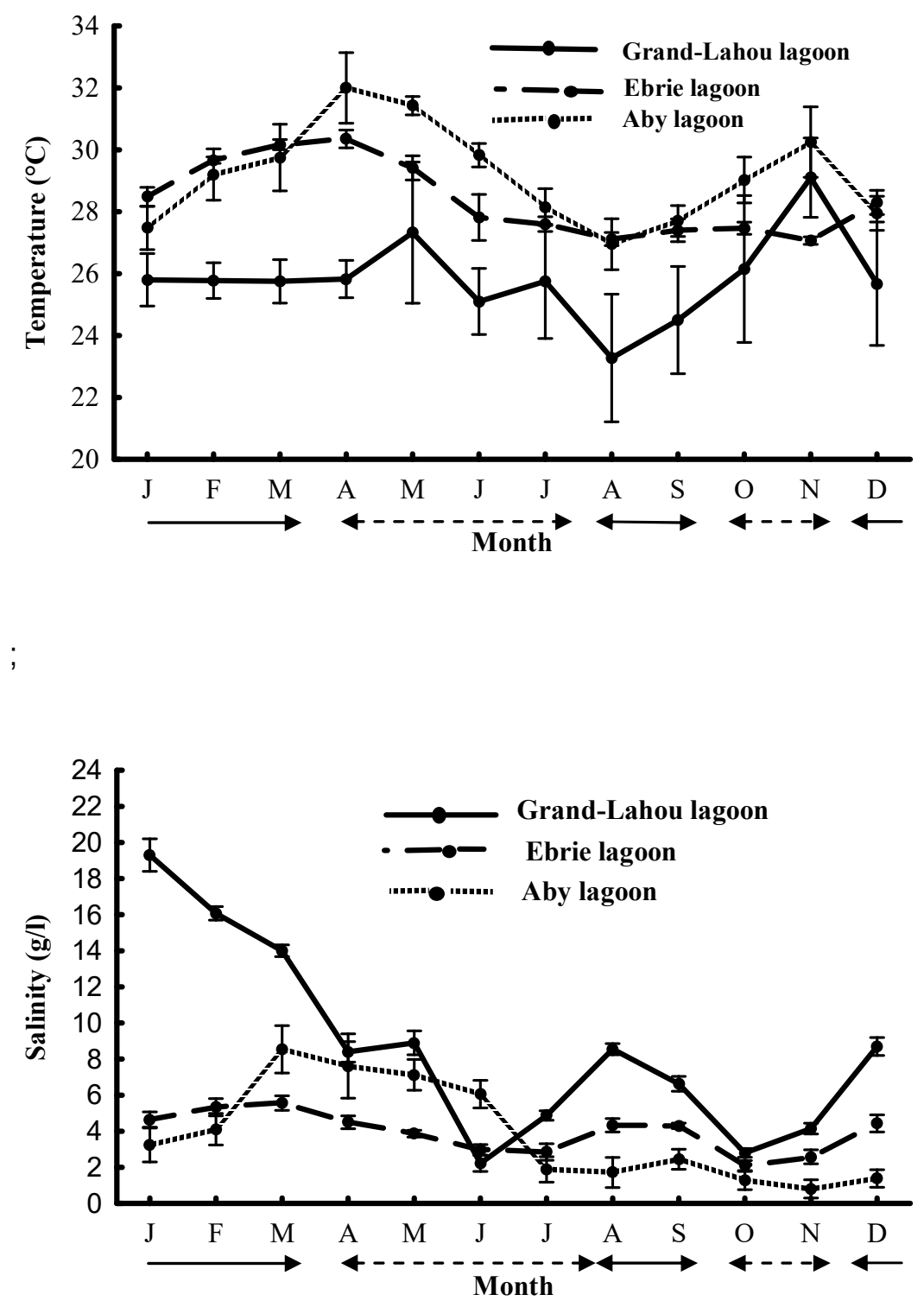

Fig. 2: Average monthly variation of water temperature and salinity from January 2007 to December 2008 in GrandLahou, Ebrie and Aby lagoons. $\longrightarrow--$ : Rainy season, $\longleftrightarrow$ Dry season.

Sampling: Fish samples were collected monthly from January 2007 to December 2008 in Grand-Lahou lagoon (Braffedon and Mackey), Ebrié lagoon (Layo and N'djem) and Aby lagoon (Adiake, Eboue and 
Assinie) using gill nets with mesh sizes of $10,12,15$, $20,25,30,35,40$ and $50 \mathrm{~mm}$. Nets were set overnight (5:00 p.m. to 6:00 a.m.) and during the following day 7:00 a.m. to 3:00 p.m.). Fish samples were identified using the key of Bauchot (1992).

Laboratory examination: In the laboratory, each individual was measured to the nearest $\mathrm{cm}$ for the fork length (FL) and weighed to the nearest $0.01 \mathrm{~g}$ for the body total mass (TM) and the eviscerated mass (EM) with a Sartorius balance (model LP 6200 S) of range $6200 \mathrm{~g}$. They were dissected and the sex was determined by the macroscopic investigation. The gonad and the liver were weighed to the nearest 0.001 $\mathrm{g}$ with a Sartorius balance (model BP $221 \mathrm{~S}$ ) of range $220 \mathrm{~g}$. Sexes were determined macroscopically after dissection. The overall sex ratio (males: females) was recorded monthly. Average length at first maturity $\left(L_{50}\right)$ was defined as the $1 \mathrm{~cm}$ length class at which $50 \%$ of the individuals of both sexes reached maturity. The percentage of sexual maturity was described by a logistic function (Ghorbel et al., 1996).

$\mathrm{P}=\frac{1}{1+\mathrm{e}^{-(\mathrm{a}+\mathrm{bFL})}} ;$ Where $\mathrm{P}=$ proportion of

mature individuals; $\mathrm{FL}=$ Fork length $(\mathrm{cm})$, and

$a$ and $b=$ constants, the value of $L_{50}$ was estimated

from the negative ratio : $L_{50}=-\frac{a}{b}$

The gonadosomatic (GSI) and the hepathosomatic (HSI) indices, which represent the gonad and digestive gland weight expressed as a percentage of the wet body weight, were estimated respectively (Vazzoler, 1996; West, 1990).

$$
\mathrm{GSI}=\frac{\text { Gonad mass }(\mathrm{g})}{\text { Eviscerate d mass }(\mathrm{g})} \times 100
$$

\section{RESULTS}

Sex ratio: A total of 2284 specimens (1406 males and 878 females) were captured during the study period. In Grand-Lahou lagoon, males (232) and females (190) were ranged in size from 11.00 to $32.00 \mathrm{~cm}$ and from 10.90 to $32.70 \mathrm{~cm}$, respectively. In Ebrie lagoon, males (437) were ranged in size from 10.10 to $29.80 \mathrm{~cm}$ and females (275) from 9.40 to $31.10 \mathrm{~cm}$. Males (737) were ranged in size from 9.00 to $31.70 \mathrm{~cm}$ and females (413)

$$
\mathrm{HSI}=\frac{\text { Liver mass }(\mathrm{g})}{\text { Eviscerate } \mathrm{d} \text { mass }(\mathrm{g})} \times 100
$$

The condition factor $(\mathrm{K})$ was also estimated according Le Cren (1951) as:

$$
\mathrm{K}=\frac{\text { Total mass }(\mathrm{g})}{(\text { Fork length }(\mathrm{cm}))^{3}} \times 100
$$

The gonad maturity stages were recorded using the Fantodji (1987) criteria with minor modifications starting from the observations on the area. Gonadal maturity stages were recognized, in females $(I=$ immature; $\|=$ resting; III = developing; IV = ripe; $V=$ ripe running; $V I=$ spent) and males (I = immature; $\|=$ developing; $I I I=$ ripe; $\mathrm{IV}=$ ripe running; $\mathrm{V}=$ spent), respectively. The absolute fecundity (AF) was determined by counting the oocytes of the ovaries in advanced vitellogenesis (stage IV). The relative fecundity was also determined by the number of eggs per gram. The relationship between absolute fecundity - fork length was described by the following equation:

$A F={ }_{\gamma}+{ }_{\beta} F L ;$

where $\mathrm{AF}=$ absolute fecundity; $\mathrm{FL}=$ Fork length; $\beta=$ slope and ${ }_{Y}=$ regression intercept. The oocyte diameter was measured using the binocular magnifying glass (model Wild M3C).

Statistical analysis: The analysis of variance (ANOVA) was used to determine the effects of the seasons and years on the gonadosomatic index, the hepatosomatic index and the condition factor in relation to sexes. The percentage of sexes was compared by the Chi-square test $\left(X^{2}\right)$. Tukey's HSD multiple contrasts test was used to determine significant differences in biological parameters across each of stage of maturity and lagoons. Significant differences were established at the 0.05 level. All Statistical analyses were carried out with the software Statistica 7.1 version.

from 8.50 to $28.80 \mathrm{~cm}$ in Aby lagoon (Fig. 2). The sex ratio was 1: 0.62 in favour of males $\left(X^{2}=122.06\right.$; $\mathrm{p}<0.05$ ) (Table 1 ). In Grand-lahou, Ebrie and Aby lagoons, the sex ratios (1:0.82), (1:0.63), and (1: $0.56)$ were significantly different from the theoretical sex ratio $1: 1\left(X^{2}=4.18 ; p<0.05\right), \quad\left(X^{2}=34.86\right.$; $p<0.05)$ and $\left(X^{2}=91.28 ; p<0.05\right)$, respectively. During the period from January to April, and November to 
December the sex ratio in males and females is (1: 1) generally.

Table 1: Number of males and females of $P$. jubelini per month and results of the Chi-square test for a sex ratio from January 2007 to December 2008 in Grand-Lahou lagoon, Ebrie lagoon and Aby lagoon. $\mathrm{M}=$ Males, $\mathrm{F}=$ Females, ${ }^{*}=$ significative difference, $p<0.05$.

\begin{tabular}{lllllllllllll}
\hline Month & \multicolumn{3}{c}{ Grand-Lahou lagoon } & \multicolumn{4}{c}{ Ebrie lagoon } & \multicolumn{3}{c}{ Aby lagoon } \\
\cline { 2 - 13 } & $\mathrm{M}$ & $\mathrm{F}$ & $\mathrm{M}: \mathrm{F}$ & $\mathrm{X}^{2}$ & $\mathrm{M}$ & $\mathrm{F}$ & $\mathrm{M}: \mathrm{F}$ & $\mathrm{X}^{2}$ & $\mathrm{M}$ & $\mathrm{F}$ & $\mathrm{M}: \mathrm{F}$ & $\mathrm{X}^{2}$ \\
\hline January & 21 & 21 & $1: 1.00$ & 0.00 & 16 & 18 & $1: 1.13$ & 0.12 & 31 & 32 & $1: 1.03$ & 0.02 \\
February & 18 & 20 & $1: 1.11$ & 0.11 & 26 & 26 & $1: 1.00$ & 0.00 & 29 & 31 & $1: 1.06$ & 0.07 \\
March & 13 & 14 & $1: 1.07$ & 0.04 & 32 & 32 & $1: 1.00$ & 0.00 & 43 & 44 & $1: 1.02$ & 0.01 \\
April & 11 & 11 & $1: 1.00$ & 0.00 & 18 & 19 & $1: 1.05$ & 0.03 & 35 & 34 & $1: 0.97$ & 0.14 \\
May & 16 & 6 & $1: 0.38$ & $4.55^{*}$ & 18 & 12 & $1: 0.66$ & 1.20 & 93 & 27 & $1: 0.29$ & $36.30^{*}$ \\
June & 13 & 8 & $1: 0.62$ & 1.19 & 54 & 21 & $1: 0.38$ & $14.52^{*}$ & 79 & 28 & $1: 0.35$ & $24.31^{*}$ \\
July & 15 & 8 & $1: 0.53$ & 2.13 & 48 & 19 & $1: 0.40$ & $12.55^{*}$ & 68 & 22 & $1: 0.32$ & $23.51^{*}$ \\
August & 13 & 2 & $1: 0.15$ & $8.07^{*}$ & 47 & 15 & $1: 0.32$ & $16.52^{*}$ & 92 & 43 & $1: 0.47$ & $17.79^{*}$ \\
September & 40 & 30 & $1: 0.75$ & 1.43 & 55 & 18 & $1: 0.33$ & $18.75^{*}$ & 123 & 51 & $1: 0.41$ & $29.80^{*}$ \\
October & 38 & 31 & $1: 0.82$ & 0.71 & 68 & 41 & $1: 0.60$ & $6.69^{*}$ & 74 & 27 & $1: 0.36$ & $21.87^{*}$ \\
November & 14 & 17 & $1: 1.21$ & 0.29 & 40 & 38 & $1: 0.95$ & 0.05 & 34 & 35 & $1: 1.03$ & 0.02 \\
December & 20 & 22 & $1: 1.10$ & 0.10 & 15 & 16 & $1: 1.06$ & 0.03 & 36 & 39 & $1: 1.08$ & 0.12 \\
Total & 232 & 190 & $1: 0.82$ & $4.18^{*}$ & 437 & 275 & $1: 0.63$ & $34.86^{*}$ & 737 & 413 & $1: 0.56$ & $91.28^{*}$ \\
\hline
\end{tabular}

Length at first maturity: The length at first maturity $\left(L_{50}\right)$ of males was slightly smaller than females with $14.48 \mathrm{~cm}$ (males) versus $15.92 \mathrm{~cm}$ (females) in GrandLahou lagoon, $12.13 \mathrm{~cm}$ (males) versus $14.70 \mathrm{~cm}$ (females) in Ebrie lagoon, and $14.03 \mathrm{~cm}$ (males) versus
$15.08 \mathrm{~cm}$ (females) in Aby lagoon (Fig. 3).The values estimated did not show a significant difference between sexes in Grand-Lahou lagoon ( $X^{2}=0.068 ; p>0.05$ ), in Ebrie lagoon $\left(X^{2}=0.038 ; p>0.05\right)$ and in Aby lagoon $(X$ $\left.{ }^{2}=0.246 ; p>0.05\right)$.

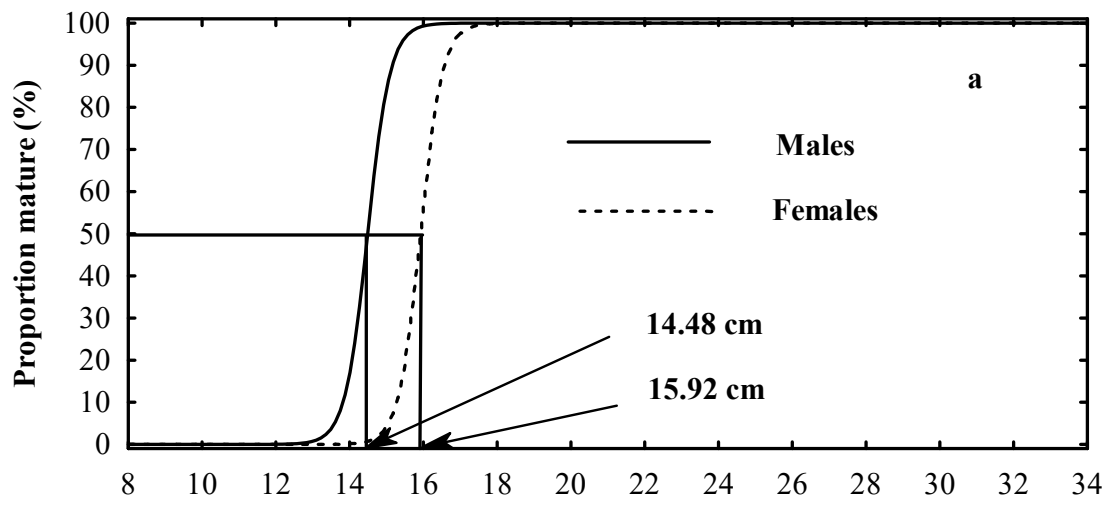



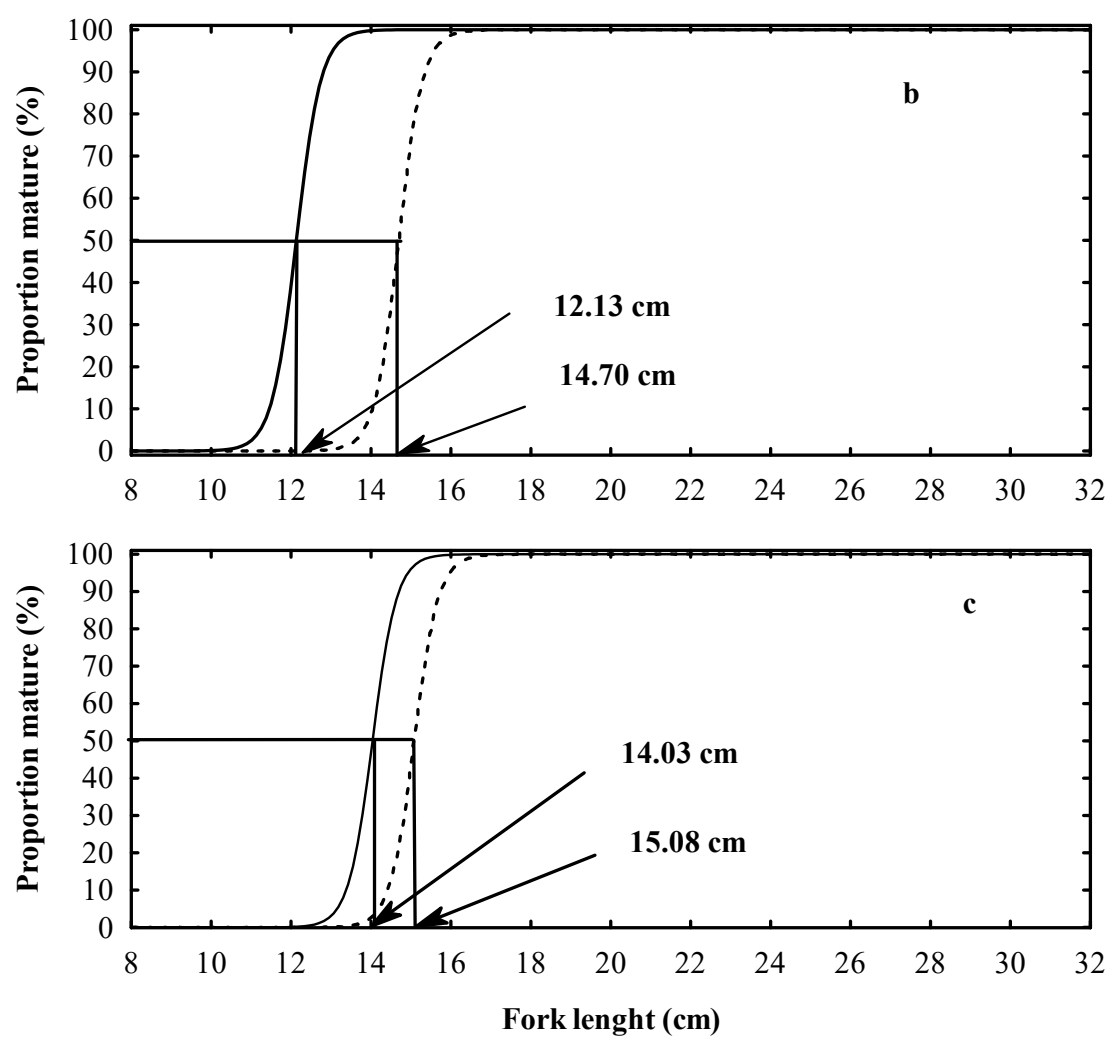

Fig. 3: Logistic curve for determining size (fork length) at first sexual maturity $\left(\mathrm{L}_{50}\right)$ for males and females of $P$. jubelini from January 2007 to December 2008 in Grand-Lahou lagoon (a), Ebrie lagoon (b) and Aby lagoon (c).

Reproductive cycle: The monthly GSI for each sex did not differ between years (ANOVA, $p>0.05$ ) and the data for the two years were therefore combined (Fig. 4). In Grand-Lahou lagoon, the GSI of males and females increased from November to January with a peak in January $(1.00 \% \pm 0.13$ and $2.56 \% \pm 0.66)$. It declined to February to April. In Ebrie lagoon, the GSI values of males and females showed a pronounced rise from November to February, reaching a peak in February $(1.60 \% \pm 0.17$ and $2.64 \% \pm 0.58)$. The GSI of both sexes decreased from March to April. In Aby lagoon, the GSI of males and females increased from November to February, peaked in February $0.66 \% \pm$ 0.12 and $2.00 \% \pm 0.41$ ), followed by a decrease from March to April. Immature individuals were found throughout the year in Grand-Lahou, Ebrie, Aby lagoons with highest percentages from May to September. The percentage of ripe gonads increased in November until $68.75 \%$ (males) and $61.11 \%$ (females) in Grand-Lahou lagoon and in December until $33.33 \%$ (males) and $35.71 \%$ (females) in Ebie lagoon. In Aby lagoon, individuals on maturation stage III and IV had significant percentages in November in males
(63.91\%) and December in females (51.28\%). In Grand-Lahou lagoon, the proportion of ripe increased from November to January $(54.16 \%$ for males and $62.50 \%$ for females), then declined to February to April. The highest values of the percentage of ripe running were observed between November and February $(65.63 \%$ for males and $63.16 \%$ for females) in Ebrie lagoon. The proportion of ripe running increased November to February $(52.00 \%$ for males and $57.69 \%$ for females), decreased from March to April in Aby lagoon. Spent individuals were found throughout the year with the highest proportion in February to March in three lagoons (Fig. 5).

Variation of hepathosomatic index and condition factor: The hepathosomatic index (HSI) varied in opposite direction compared to the GSI. The highest values of the $\mathrm{HSI}$ of males and females were found in April $(0.95 \% \pm 0.07$ and $1.20 \% \pm 0.06)$ in Grand-Lahou lagoon. The highest values for males and females were observed in April (1.05 \% \pm 0.11 and $1.44 \% \pm 0.07)$ in Ebrie lagoon. $\mathrm{HSI}$ values were high in April $(1.10 \% \pm$ 0.15 and $1.26 \% \pm 0.12$ for males and females respectively) in Aby lagoon. 
Bodji et al. J. Appl. Biosci. 2013. Reproductive biology of Sompat grunt, Pomadasys jubelini in Côte d'Ivoire

The condition factor $(\mathrm{K})$ and the gonadosomatic index (GSI) varied in the same direction. In Grand-Lahou lagoon, the highest values of males and females were observed in January $(1.70 \% \pm 0.04$ and $1.72 \% \pm$
0.01). In Ebrie lagoon and Aby lagoon, $\mathrm{K}$ values were high in February $(1.65 \% \pm 0.02$ and $0.70 \% \pm 0.11)$ for males and $(1.72 \% \pm 0.02$ and $0.88 \% \pm 0.06)$ for females (Fig.4). 

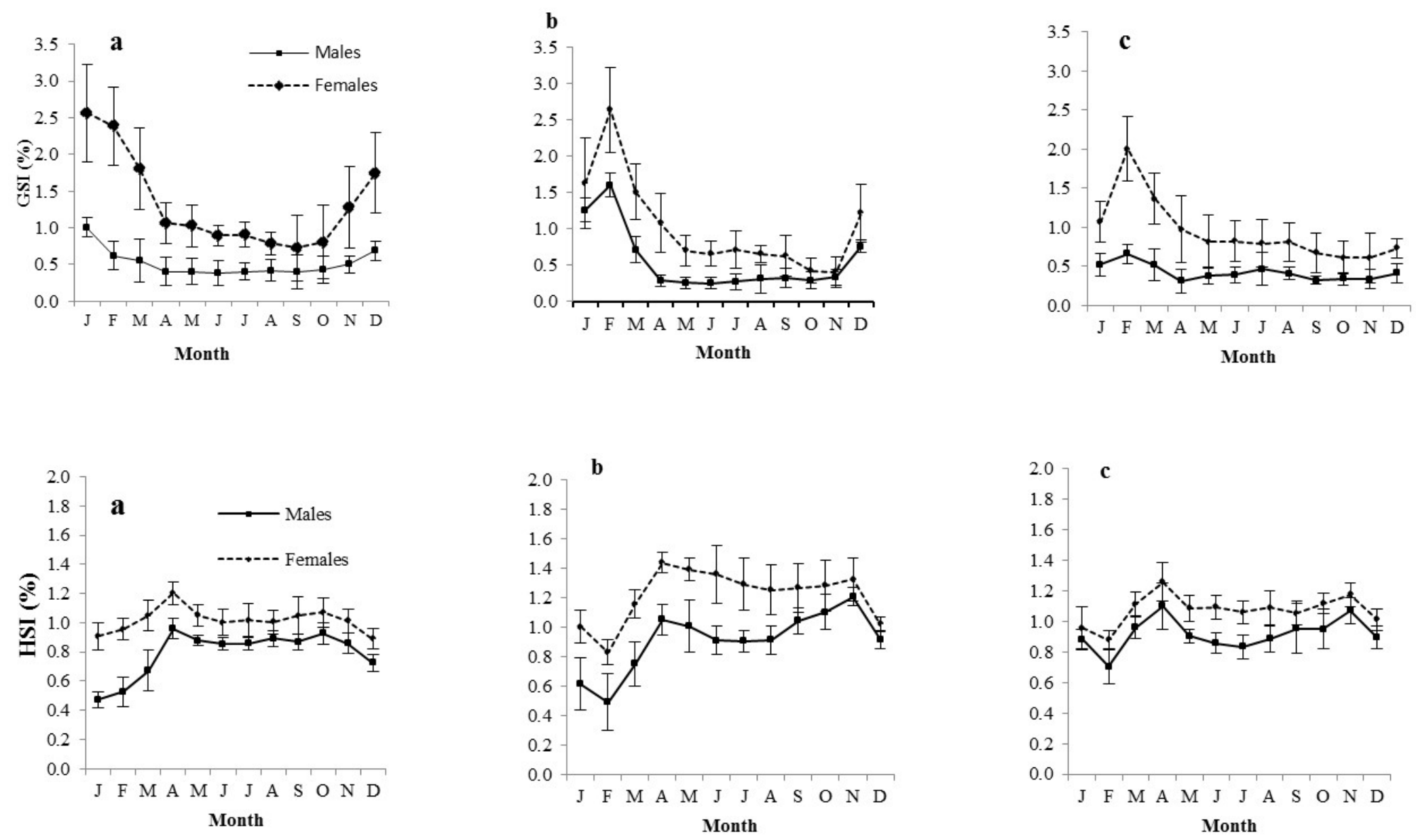

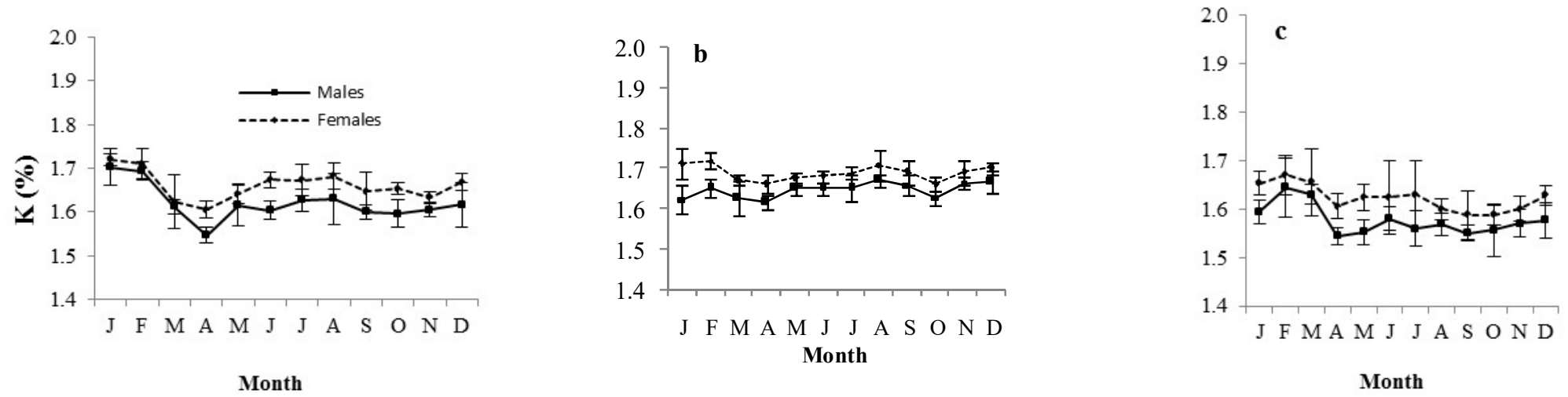

Fig. 4: Monthly variations of the gonadosomatic index (GSI), hepathosomatic index (HSI) and condition factor (K) for males and females of $P$. jubelini from January 2007 to December 2008 in Grand-Lahou (a), Ebrie (b) and Aby (c) lagoons. 
Fecundity and oocyte diameter: The absolute fecundity ranged from 46856 to 131208 eggs for females with size varying between 14.20 and $26.50 \mathrm{~cm}$ (FL) in Grand-Lahou lagoon, from 46184 to 126959 eggs for females between 14.50 and $27.00 \mathrm{~cm}(\mathrm{FL})$ in Ebrie lagoon and from 17184 to 129459 eggs for females of 10.40 to $27.10 \mathrm{~cm}$ (FL) in Aby lagoon. This fecundity was positively correlated with the fork length $\left(r^{2}=0.46 ; P<0.05\right),\left(r^{2}=0.39 ; P<0.05\right)$ and $\left(r^{2}=\right.$ $0.43 ; P<0.05)$ respectively in Grand-Lahou, Ebrie and Aby lagoons (Fig. 6). The mean relative fecundity was $803 \pm 201 ; 772 \pm 264$ and $928 \pm 376$ eggs per gram of body weight in Grand-Lahou, Ebrie and Aby lagoons respectively. The oocyte diameter frequency distribution is from the ovaries at different stages of sexual maturity $(4,5$ and 6$)$ is unimodal (Fig. 7$)$.

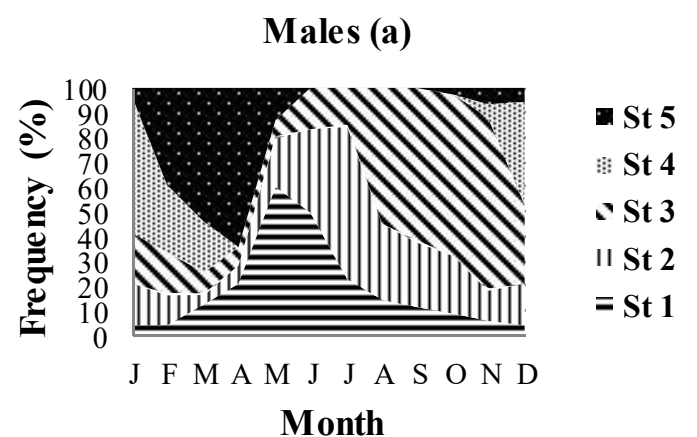

Males (b)

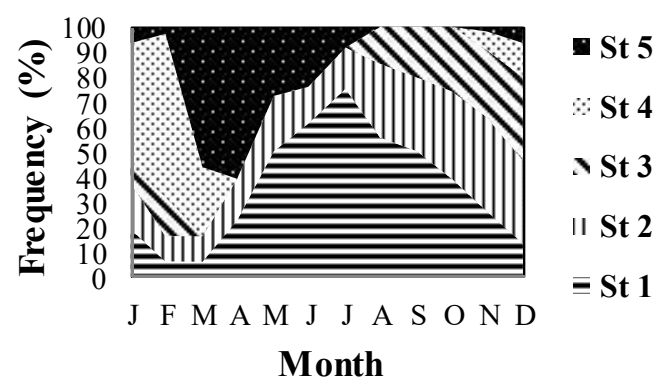

Month

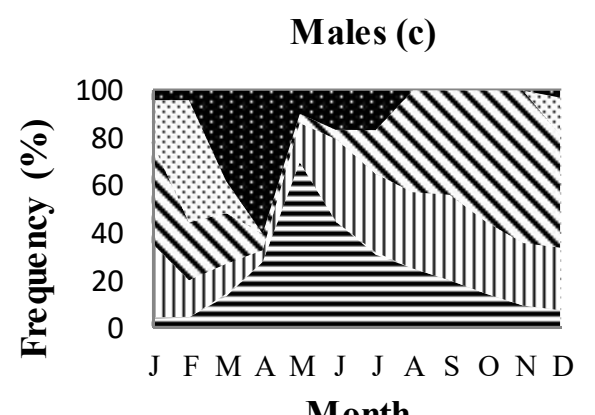

Month
Females (a)

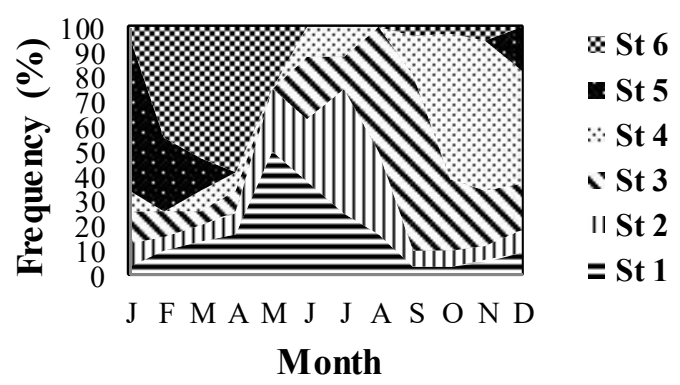

Females (b)

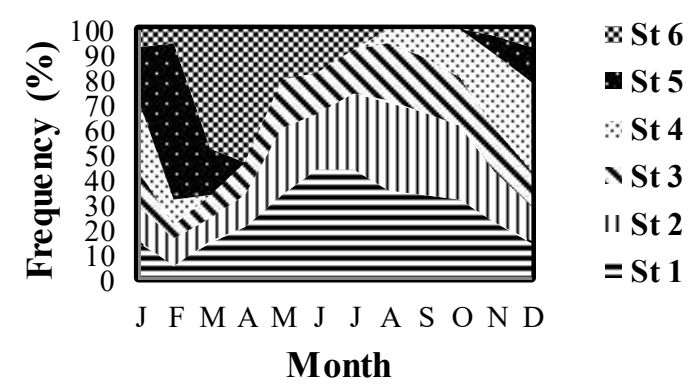

Females (c)
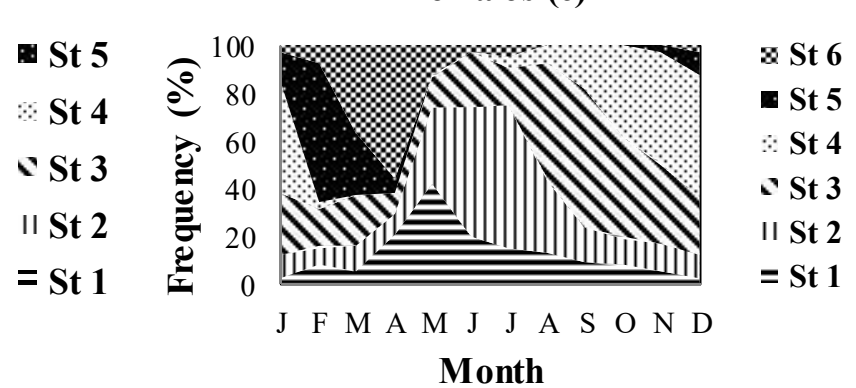

Fig. 5: Percentage of different maturation stages for males and females of $P$. jubelini from January 2007 to December 2008 in Grand-Lahou (a), Ebrie (b) and Aby (c) lagoons respectively; St = Stage. 

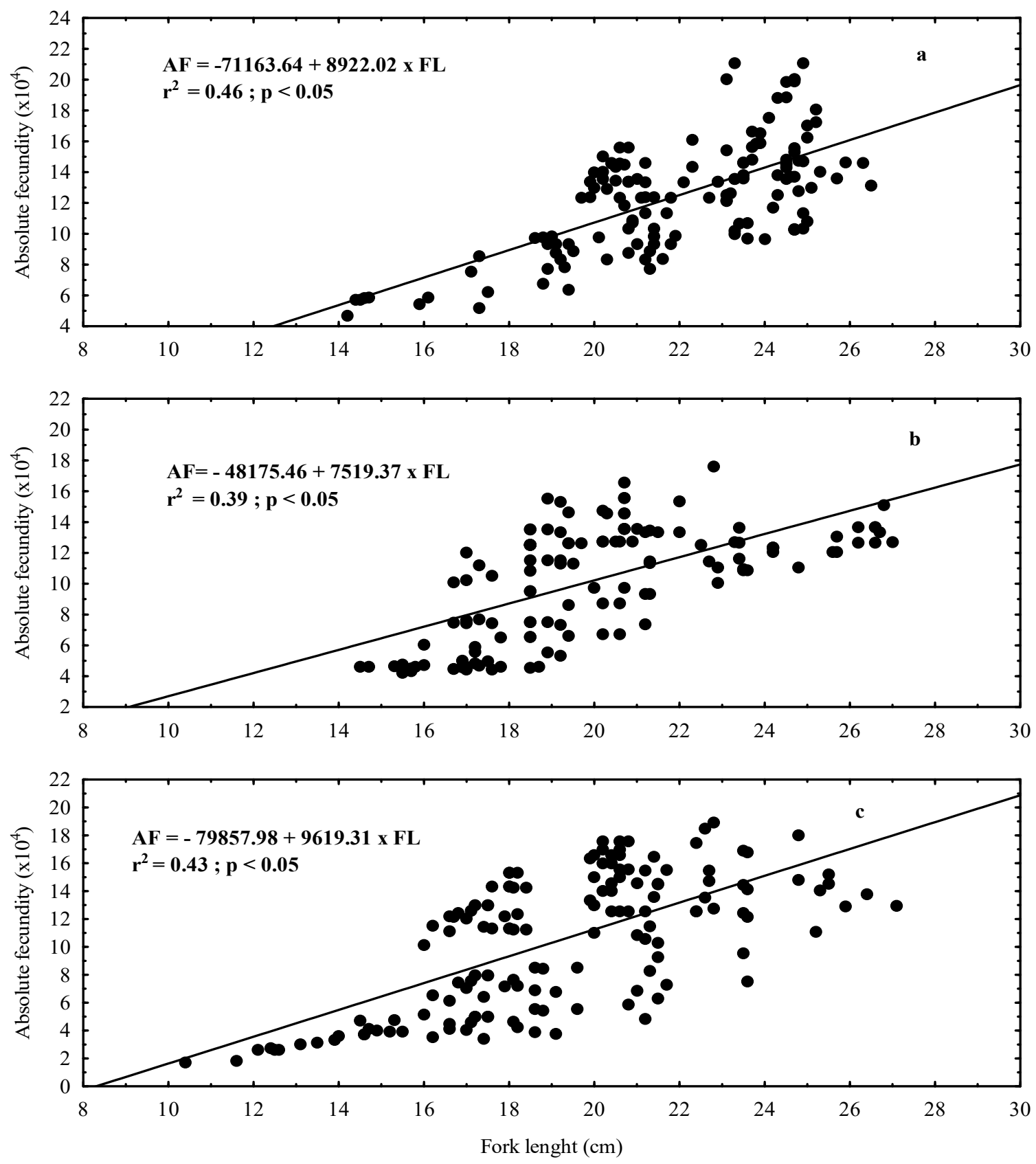

Fig. 6: Relationship between the absolute fecundity and the fork length of $P$. jubelini from January 2007 to December 2008 in Grand-Lahou (a), Ebrie (b) and Aby (c) lagoons respectively.

The stage 4 varied between 0.32 and $0.60 \mathrm{~mm}$ in Grand-Lahou lagoon, and between 0.32 and $0.58 \mathrm{~mm}$ in Ebrie and Aby lagoons. The averages of oocytes diameters were $0.455 \pm 0.036 \mathrm{~mm}$ in Grand-Lahou lagoon, $0.447 \pm 0.044$ in Ebrie lagoon and $0.436 \pm$ $0.041 \mathrm{~mm}$ in Aby lagoon. According to the stage 5, the mode ranged from 0.48 to $0.80 \mathrm{~mm}$ in Grand-Lahou lagoon and Ebrie lagoon respectively, and from 0.48 to $0.84 \mathrm{~mm}$ in Aby lagoon. As for stage 6, the mode was ranged between 0.28 and $0.60 \mathrm{~mm}$ in three lagoons. The averages of oocytes diameters of stage 5 and stage 6 were $0.59 \pm 0.05 \mathrm{~mm}$ and $0.40 \pm 0.03 \mathrm{~mm}$ in Grand-Lahou lagoon respectively, $0.59 \pm 0.05 \mathrm{~mm}$ and $0.41 \pm 0.03 \mathrm{~mm}$ in Ebrie lagoon respectively, and were 
$0.59 \pm 0.06 \mathrm{~mm}$ and $0.41 \pm 0.05 \mathrm{~mm}$ in Aby lagoon respectively.
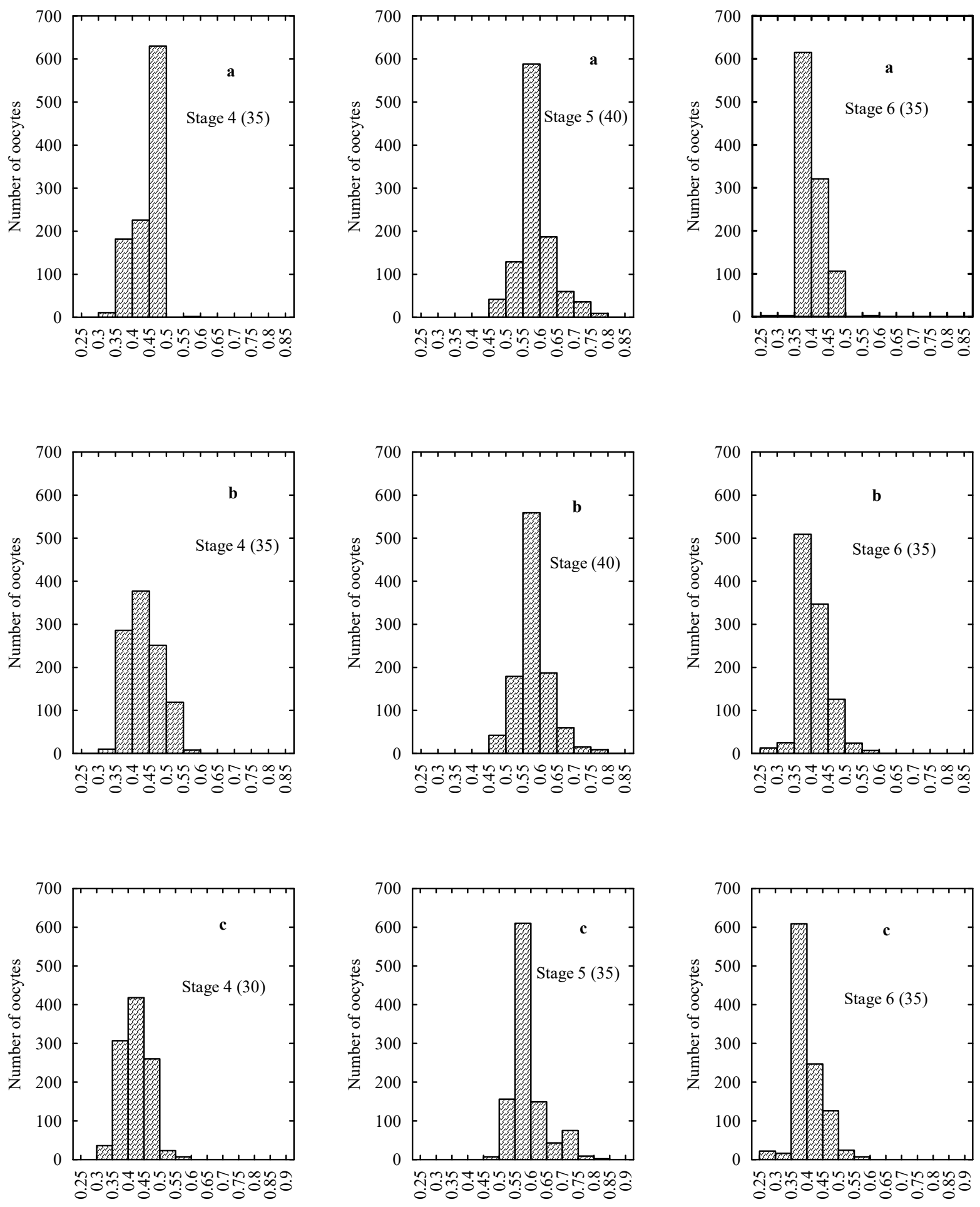

Oocyte diameter $(\mathrm{mm})$

Oocyte diameter (mm)

Oocyte diameter $(\mathrm{mm})$

Fig. 7: Frequency distribution of oocyte diameter in the gonads at macroscopic stages of Pomadasys jubelini from January 2007 to December 2008 in Grand-Lahou lagoon (a), Ebrie lagoon (b) and Aby lagoon (c). 


\section{DISCUSSION}

Pomadasys jubelini is a gonochoric species with no evidence of sexual dimorphism, as for all species of the genus Pomadasys (Pajuelo et al., 2002). In the present study, the sex ratio was (1: 0.82) in Grand-Lahou lagoon, (1: 0.63) in Ebrie lagoon, and (1: 0.56) in Aby lagoon in favour of males. Fantodji (1987) noted similar observation (1: 0.81) for this species in Ebrie lagoon. This result was different to that reported for Pomadasys incisus observed in the Gulf of Tunis (Chakroun and Ktari, 2006). The author reported an unbalanced sex ratio in favour of females (1: 2.5). According to Mellinger (2002) several hypothesis such as the migration for feeding, the difference of growth and the mortality rate by sexes could explain these results. The difference of growth rate between sexes and differential migration by sex could probably explain our results. In fact, Palazon-Fernandez (2007) noted that females have higher energy requirements for reproduction than males, causing a slower growth rate. Bowering (1976) pointed out that differences in growth between sexes are the result of genetics that determines the physiology and behaviour of fish. The size at first maturity of males was slightly lower than females $(14.48 \mathrm{~cm}$ versus $15.92 \mathrm{~cm}$ in Grand-Lahou lagoon, $12.13 \mathrm{~cm}$ versus $14.70 \mathrm{~cm}$ in Ebrie lagoon, and 14.03 $\mathrm{cm}$ versus $15.08 \mathrm{~cm}$ in Aby lagoon). These sizes were similar to those observed in Ebrie lagoon for which ranged between $12 \mathrm{~cm}$ and $16 \mathrm{~cm}$ (Fantodji, 1987). This study results were also different from one lagoon to another. According to Lowe-McConnell (1987) the length at first maturity can be correlated with the water area. Several works showed that the length at first maturity of same species could vary with growth rates, fishing removals, food, and hydrologic conditions (Hood and Johnson, 2000; Potts and Manooch, 2001).The seasonal variations of maturity stages and the gonadosomatic index showed that spawning seasons occurred from November to April in Grand-Lahou, Ebrie and Aby lagoons. The highest proportion of ripe and running females was observed between November and February. The gonadal maturation occurred from

\section{ACKNOWLEDGEMENTS}

The authors wish to thank the Centre de Recherches Oceanologiques (CRO) which took part in the field work. This study would not have been possible without the financial support of this institute. Thanks to all the
November to February however, the spawning took place between February and April in the three lagoons .The spawning seasons coincided with the major dry seasons when abiotic parameters such as temperature and salinity were very high (Durand and Guiral , 1994). According to Chikou et al., (2007) the temperature is considered to be the most important factor influencing the fish reproduction. Also, the success of reproduction could be the result of salinity conditions that are favourable for the osmotic requirements (Chaoui et al., 2006). P. jubelini belong to species of marine origin which live in the estuaries (Albaret, 1994). During sampling the majority of mature individuals were collected in the area near the sea. Sexual reproduction has metabolic costs. During the raining season fish ate actively then stocked hepatic reserves in the liver for the gamete development and somatic reserves in the body fat for the spawning. The using hepatic reserves during the gonadal maturation caused the lowest HSI values. The energy invested into spawning seems to be the main factor responsible for the observed decrease in the somatic growth of $P$. jubelini. Thus they could use hepatic and somatic reserves to generate and ripen gametes, as well as to release them. This reproductive strategy using the biotic and abiotic factors was announced at other teleost fish (Paugy, 2002; Sylla et al., 2009). The fecundity was very high in the three lagoons. This fact was already described in other teleost fish such as using in the Baoule River the strategy characterised by high fecundity, absence of parental care (Paugy, 2002). The absolute fecundity was positively correlated with the size of females in all lagoons. Several authors noted similar results (Atse et al., 2009; Palazon-Fernandez, 2007; Sylla et al., 2009). The reproductive strategy among $P$. jubelini was synchronous determinate and total spawning. All the oocytes develop and ovulate at the same. Such ovaries may be found in teleosts that spawn once and then die, such as anadromous Oncorhynchus species (Mura and Saborido-Rey, 2003).

staff members of the department aquaculture of the CRO (researchers, technicians and students) that assisted in carrying out the work. 


\section{REFERENCES}

Albaret, J.J., 1994. Les poissons : biologie et peuplements in : Environnement et ressources aquatiques de Côte d'Ivoire. Tome II - Les milieux lagunaires (Durand J.R., P.Dufour, D. Guiral, S.G.F. Zabi) éds, ORSTOM, paris, 239-279.

Atsé, B.C., K.J.Konan, N.J. Kouassi, 2009. Biologie de la reproduction du Cichlidae Tylochromis jentinki dans la lagune Ebrié (Côte d'Ivoire). Cybium 573

Bauchot, M.L. and J.C. Hureau, 1990. Sparidae, in: check -list of the fishes of the Eastern Tropical Atlantic. Clofeta II. In: J.C. Quero, Hureau, C. Karrer, A. Post and L. Saldanha (Eds). UNESCO Paris, pp. 790-812.

Bauchot, M.L., 1992. Haemulidae, in: Faune des poissons d'eaux douces et saumâtres de l'Afrique de l'Ouest. Tome II (Paugy D., C.Levèque, G.G.Teugels) éds, IRD Paris, pp. 498-503.

Bowering, W., 1976. Distribution, age and growth and sexual maturity of witch flounder (Glyptocephalus cynoglossus) in Newfoundland Waters. J. Fish. Res.Bd. Can., 33: 1574-1584.

Chakroun-Marzouk, N. and M.H. Ktari, 2006. Caractéristique de la reproduction et de la croissance pondérale relative de Pomadasys incisus (Haemulidae) du golf de Tunis. Cybium, 30 (4) : 333-342.

Chaoui, L., M.H. Kara, E. Faure and J.P. Quignard, 2006. Growth and reproduction of the gilthead seabream Sparus aurata in Mellah lagoon (north-eartern Algeria). Sci. Mar., 70 (3) 545552.

Chikou, A., P. Lalèyè, J.C. Philippart and P. Vandewalle, 2007.Quelques aspects de la biologie de reproduction chez Clarias ebriensis (Siluriformes, Clariidae) dans le delta de l'Ouémé au Bénin (Afrique de l'Ouest).Cybium, 31(2) : 207-215.

Durand, J.R., D. Guiral, 1994. Hydroclimat et hydrochimie. In : Environnement et ressources aquatiques de Côte d'Ivoire. Tome II. Les milieux lagunaires (Durand J.R., P.Dufour, D. Guiral, S.G. Zabi) éds, Paris : ORSTOM, pp. $129-136$.

Durand, J.R. and M. Skubich, 1979. Les lagunes ivoiriennes, Doc. Multigr. C R O, Abidjan, 55 p.
Durand, J.R. and M. Skubich, 1982. Les lagunes ivoiriennes, Aquacul., 27: 211-250.

Fantodji, A., 1987. Biologie et Physiologie de la reproduction des Pomadasys jubelini (Cuvier) (Poissons Téléostéens) des lagunes et mer de Côte d'Ivoire. Thèse Océanographie biologique, Faculté des Sciences et Techniques, Université Nationale de Côte d'Ivoire $130 \mathrm{p}$.

Ghorbel, M., O. Jarboui, M.N. Bradai and A. Bouain, 1996. Détermination de la taille de première maturité sexuelle par une fusion logistique chez Limanda Limanda, Pagellus erythrinus et Scorpaena porcus, Bull. INSTM, n. spec., 3: 24-27.

Hood, P. and A.K. Johnson, 2000. Age, growth, mortality, and reproduction of red porgy, Pagrus pagrus, from the eastern Gulf of Mexico. Fish. Bull., 98: 723-735.

Lae, R., 1982. Premières observations sur la pêche en lagune de Grand-Lahou, D.E.A Océanographie Tropicale, Université de Brest, paris, $30 \mathrm{p}$.

Le Cren, E.D., 1951. The length-weight relationship and seasonal cycle in gonad weight and condition in the perch (Perca fluviatilis). J. Ani. Ecol., 26: 201-209.

Lowe-Mcconnell, R.H., 1987. Breeding behaviour patterns and ecological differences between Tilapia species and their significance for evolution within the genus Tilapia (Pisces, Cichlidae).Proc. Zool. Soc., 132: 1-30.

Marshall,C.T., L. O'Brien, J. Tomkiewicz, F.W. Köster, G. Kraus, G. Martteinsdottir, M.J. Morgan, F. Saborido-Rey, J.L. Blanchard, D.H. Secor, P.J. Wright, N.V. Mukhina and H. Bjornsson, 2003. Developing alternative indices of reproductive potential for use in fisheries management, cases studies for stocks spawning, an information gradient. J. Northw. Atl. Fish. Sci. 33, 161-190.

Mellinger, J., 2002. Sexualité et reproduction des poissons, CNRS éditions, Paris, $349 \mathrm{p}$.

Murua H. and F. Saborido-Rey , 2003. Female reproductive strategies of marine Fish species of the North Atlantic. J. Northw. Atl. Fish. Sci. 33, 23-31.

N'goran, Y.N., 1995. Biologie, écologie et pêche de l'Ethmalosa fimbriata (Bowdich, 1825) en 
lagune Aby Côte d'Ivoire. Thèse de Doctorat de l'Université de Bretagne Occidental. Spécialité Océanographie biologique, 227p.

Pajuelo, J.G., J.M. Lorenzo and M. Gregoire, 2002. Life history of pomadasys incisus (Osteichthyes: Haemulidae) in the Canarian Archipelago. Sci. Mar., 67(2): 241-248.

Palazon-Fernandez, J.L., 2007. Reproduction of the White grund, Haemulon plumieri (Lacépède, 1802) (Pisces: Haemulidae) from Margarita Island, Venezuela. Sci. Mar., 71 (3) 429-440.

Paugy, D., 2002. Reproductive strategies of fishes in tropical temporary stream of the Upper Senegal basin: Baoule River in Mali. Aquat. Living Resour. 15: 25-35.

Paugy, D., C. Levèque and G.G. Teugels, 2003. Faune des poissons d'eaux douces et saumâtres de I'Afrique de l'Ouest. Tome II, IRD, Paris, 815 pp.

Potts, J.C. and C.S. Manooch III, 2001. Differences in the age and growth if the white grunt (Haemalon plumieri) from North Carolina and South Carolina compared with Southeast Florida. Bull. Mar. Sc. 68 (1): 1-12.

Sun ,C., Y. Chang, C., Tszeng, S. Yeh and N. Su, 2009. Reproductive biology of blue marlin (Makaira nigricans) in the western Pacific Ocean.Fish.Bull.107: 420-432.

Sylla, S., B.C. Atsé and N.J. Kouassi, 2009. Stratégie de reproduction du Carangidae Trachinotus teraia Cuvier, 1832 dans la lagune Ebrié (Côte d'Ivoire).Sc.Nat., 6 (1) : 83 - 94.

Vazzoler, A.E.A.M, 1996. Biologia da reproducão de Peixes Teleósteos. Teoria e prática. Maringá, 169 pp.

West, G., 1990. Methods of assessing ovarian development in fishes: a review. Aust.J. Mar. Freshw. Res., 41: 199-222. 